\title{
Okhotsk Finwhale (Balaenoptera physalus) Modern Distribution and Abundance
}

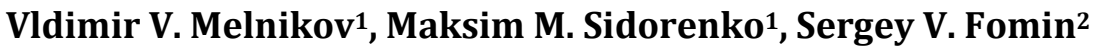 \\ ${ }^{1}$ V.I. Il'ichev Pacific Oceanological Institute (POI), Vladivostok, Russia \\ ${ }^{2}$ Kamchatka Branch of the Pacific Geographical Institute, Far East Brunch of Russian Academy of Sciences, \\ Petropavlovsk-Kamchatsky, Russia \\ Email: vmelnikov@poi.dvo.ru
}

How to cite this paper: Melnikov, V.V., Sidorenko, M.M. and Fomin, S.V. (2017) Okhotsk Finwhale (Balaenoptera physalus) Modern Distribution and Abundance. Open Access Library Journal, 4: e3250. http://dx.doi.org/10.4236/oalib.1103250

Received: November 21, 2016

Accepted: January 10, 2017

Published: January 13, 2017

Copyright (อ 2017 by authors and Open Access Library Inc.

This work is licensed under the Creative Commons Attribution International License (CC BY 4.0).

http://creativecommons.org/licenses/by/4.0/

(c) (i) Open Access

\begin{abstract}
Population of finwhales in north part of Pacific was exposed to excessive commercial pressure and was almost completely eliminated. Information about finwhales in the Sea of Okhotsk after ending is very poor. Observation of whales in the Okhotsk Sea was performed in June, July 2014 and April 2015 from ships travel to a research polygon, carrying out the following records: date, location of animal, species and number, their movement in relation to the vessel, the visual distance from the vessel to the whale, the intensity of their movements. In late June 2014, 40 individuals in 26 groups of finwhales were taken into account. On average, 10.12 individuals per 100 nautical miles of counting route are calculated. On 27 July 2014 during motion along the coast of eastern Sakhalin, we accounted 14 finwhales in 6 groups in total. On 27 July 2014, during motion along the coast of eastern Sakhalin, we accounted 14 finwhales in 6 groups in total of which are 3.55 groups and 8.28 individuals per 100 nautical miles of accounting route on average. The synthesis of the available literature information and own data shows 2- to 3-fold increase in the number of finwhales in the Sea of Okhotsk in last decades. Such a significant number of finwhales in Okhotsk Sea did not register any initial period of whaling or in the period of its development.
\end{abstract}

\section{Subject Areas \\ Marine Biology}

\section{Keywords}

Okhotsk Sea, Finwhale, Distribution, Abundance

\section{Introduction}

Finwhale is a second largest ocean inhabitant. This is an important commercial 
species which for a long time has kept the global whaling industry [1]. As a result, the population of finwhales was exposed to excessive commercial pressure and was almost completely eliminated. In contrast to the Pacific waters and Bering Sea, in the initial period of whaling, and later, the finwhale is not taken in the Okhotsk Sea in significant amounts. Whaling in the Okhotsk Sea was concentrated within 150 - 200 mile zone of northern Kuril Islands and western waters near Kamchatka. This is due location of coastal whaling station [2]. In the central and northern parts of the Okhotsk Sea whaling for finwhales was not conducted. Japanese whaling of finwhales was carried on in the extreme southern part of the Okhotsk Sea only where worked the coast whaling station "Sanriku" located on the northern coast of Hokkaido [3].

In classical reviews devoted study of cetaceans during whaling, information about finwhales in the Sea of Okhotsk is very poor. So, Sleptsov (1955) [4] [5] stated that the finwhales inhabited off the east coast of Sakhalin Island. Particularly finwhales met common off Cape Terpeniya. Singles and small groups of whales were seen near the Iona Island, to south of Tauyski gulf, in the north-eastern and central parts of the sea, and along the western coast of Kamchatka. Tomilin [1] (1957) reported that near the western shores of Kamchatka finwhales appeared in June, held all summer and disappeared in the fall. Later, Sleptsov (1961) [2] pointed out that the finwhale was permanently found near Kurile ridge, at the eastern coast of Sakhalin Island, off the west coast of Kamchatka, in the Sakhalin Bay, area of Iona Island in the western part of the Okhotsk Sea, and, apparently, penetrated into the Shelikhov Gulf. It was assumed that finwhales in the Sea of Okhotsk are distributed more or less evenly, and their number is not high [2] [4].

In 2014 and 2015, we conducted observation of finwhales in the Okhotsk Sea. In addition, we performed synthesis of available information about current state population of finwhales in the Okhotsk Sea, which is the main objective of this work.

\section{Material and Methods}

In 2014, observing and registration of marine mammals were perform from the navigation bridge of a ship, height is above sea level is 7 meters. From this height at a good visibility has been viewed water area within a radius of 4.5 miles or 8 kilometers. Carry out the following records: date, location of found animal, the route and the ship's course, sea state, visibility, intensity of solar glare and its location, animal species and number of animals, their movement in relation to the vessel, the visual distance from the vessel to the animals, the intensity of their movements. On the results affected the weather significantly. During the summer, considerable segment of work time was complicated by the fog. In April 2015 observations were carried out from vehicle refrigerator. The height of the observation above the sea level is 18 meters (including immersion of ship). This height be able to watch water surface within 8 miles. The speed of movement of the vessel was 13 - 15 knots. Observations were both by the naked eye and bino- 
culars 8 times. During the works used GPS navigators, photo and movie cameras. In processing data we used Excel, GraphPad Prism, Statistica, ArcMap.

\section{Results}

In late June 2014, observations were made in the period vessel travel to area of a research polygon. During movement of vessel a single, pair and group of three finwhales we met regularly at distance of 150 to $5000 \mathrm{~m}$ away from the ship's course. June 27 we account 15 finwhales including 6 singles, 3 pairs and 1 group of three individuals. Only one finwhale found on June 28 . On June 29 we registered 24 individuals. During this day, in addition to 12 singles we met three groups of 3 and one group of 4 finwhales. Animals were concentrated in the Gulf of Terpeniya and in the central part of the Okhotsk Sea (Figure 1). A total were taken into account 40 individuals in 26 groups finwhales (Table 1). On average, we registered 10.12 individuals per 100 miles of counting route.

On 27 July 2014 we were discovered an aggregation of 13 finwhales during our

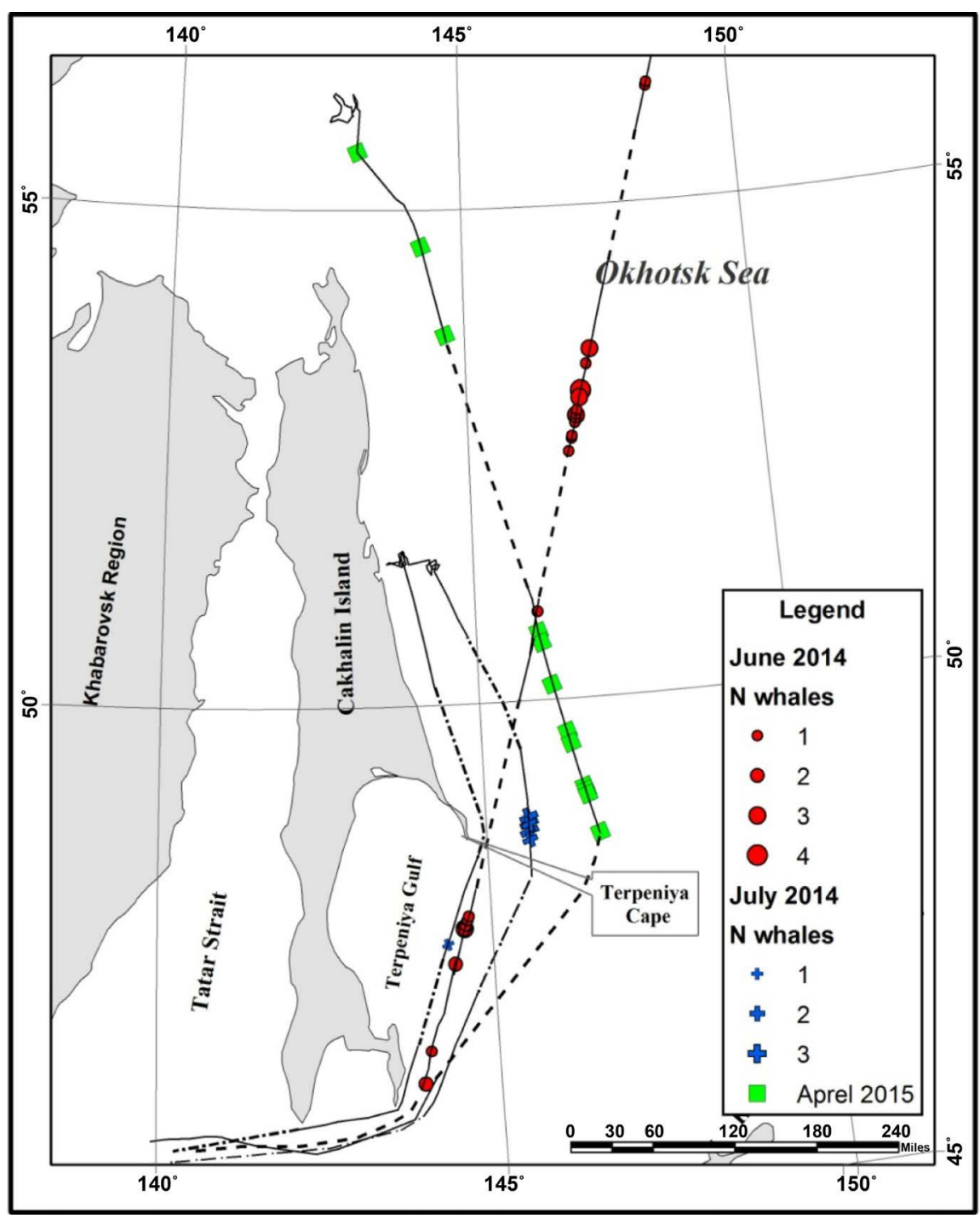

Figure 1. Distribution of finwhale in July - August 2014 and April 2015 in Okhotsk Sea. 
Table 1. Results ship based incidental acounts finwhales in Okhotsk Sea.

\begin{tabular}{|c|c|c|c|c|c|c|}
\hline \multirow{2}{*}{ Period of works } & \multirow{2}{*}{$\begin{array}{c}\text { Covered } \\
\text { distance } \\
\text { with works }\end{array}$} & \multicolumn{2}{|c|}{ Counted finwhales } & \multirow{2}{*}{$\begin{array}{l}\text { The average number of } \\
\text { individuals in groups }\end{array}$} & \multirow{2}{*}{$\begin{array}{l}\text { Number of groups } \\
\text { registered per } 100 \text { miles }\end{array}$} & \multirow{2}{*}{$\begin{array}{l}\text { Number of individuals } \\
\text { registered per } 100 \text { miles }\end{array}$} \\
\hline & & individuals & groups & & & \\
\hline $27.06-30.062014$ & 395 & 40 & 26 & $1.54(\min =1, \max =4)$ & 6.58 & 10.12 \\
\hline $26.07-8.082014$ & 169 & 14 & 6 & $2.33(\min =1, \max =3)$ & 3.55 & 8.28 \\
\hline $18-27.042015$ & 365 & 11 & - & 1 & - & 3.01 \\
\hline
\end{tabular}

transition to the work site. Alone, in pairs and threes animals kept to the east of the southern tip of Terpeniya Cape (Figure 1). Two groups of finwhales intensively moved to the east, crossing the course of the vessel. Other animals dive for a long time under water and were discover only by one exit to the surface. On the return trip we met a single individual in the Gulf of Terpeniya. During motion along the coast of eastern Sakhalin and back we accounted 14 finwhales in 6 groups total. On average, we accounted 3.55 groups and 8.28 individuals per 100 miles of route (Table 1 ).

In 2015, work was carried out mainly 25 and 26 April during movement of ship to south through central part of Okhotsk See. On leaving the fields of drifting ice we observed outputs of 3 unidentified whales. Later the singles of finwhales was registered in the ice-free waters throughout the entire journey to south (Figure 1). Most of finwhales were moving in a northerly direction towards the ship. In whole we accounted 11 finwhales, or 3.01 individuals on average per 100 miles of accounting route (Table 1).

\section{Discussion}

After 1975, in the initial period of prohibition commercial whaling in the North Pacific, information about finwhales in Okhotsk Sea was extremely scarce, scattered and fragmentary (Table 2). In most papers were reported about incidental and encounters meets of finwhales during various expeditions related to fisheries [6] [7] [8] [9]. Thinking about number of finwhales in the Okhotsk Sea based on expert supposition. So, Sobolewski [10] supposed that in Okhotsk Sea 300 finwhales. Later after 4 years Berzin and Vladimirov [6], on the basis own materials and "processing of observations of Soviet research vessels operating in the Sea of Okhotsk" bring the same number of 200 - 300 animals. On results of observations in 1990 V.L. Vladimirov [8] identified the approximate number of finwhales in the Sea of Okhotsk by 2.7 thousand individuals and the stock size prior to commercial explotation 5 - 5.5 thousand. Certain information about discovers of finwhales in the Sea of Okhotsk given by Shuntov [9], who agrees with the assessment of V.l. Vladimirov [8] - 2.7 thousand. Unfortunately authors not give any information about length of accounting routes, methods of accounting and recorded number of animals, how calculate the amount, not mention the statistical processing and validity of number.

Since 1989 joint Japanese-Russian scientific expedition on account of marine mammals in the Okhotsk Sea are conducted. These works are accented on minke 
Table 2. Results of observation of finwhales in Okhotsk Sea according to the literature.

\begin{tabular}{ccccc}
\hline Date & $\mathrm{n}$ & n. group & Where & Source \\
\hline May 1974 & 5 & & Iturup Okhotsk side & {$[6]$} \\
October 1975 & 10,5 & & To NE cape Aniva, Sakhalin & {$[6]$} \\
August 1967 & 5 & 2 & To E off cape Terpenia & {$[11]$} \\
June - July 1988 & 10 & 1 & First Kuril Strait & {$[8]$} \\
August 1989 & 28 & $?$ & Okhotsk Sea without Shelikhov Bay & {$[8]$} \\
1990 & 53 & $?$ & Okhotsk Sea & {$[8]$} \\
1992 & 79 & $?$ & Okhotsk Sea & {$[8]$} \\
Summer 1988 and 1991 & 14 & 3 & Okhotsk Sea & {$[7]$} \\
Autumn 1984 and 1986 & 6 & 1 & Okhotsk Sea & {$[7]$} \\
July- August 1993 & 5 & 2 & South of Okhotsk Sea & {$[12]$} \\
July - August 1997 & 25 & 5 & Okhotsk Sea & {$[12]$} \\
\hline
\end{tabular}

Table 3. Comparative results of surveys finwhales and minke whales in the Sea of Okhotsk 1989 - 2010 according to the literature.

\begin{tabular}{cccccc}
\hline \multirow{2}{*}{ Date } & \multicolumn{2}{c}{ Finwhale } & \multicolumn{2}{c}{ Minke whale } & \\
\cline { 2 - 5 } & Number $(\mathrm{n})$ & $\begin{array}{c}\mathrm{n} / 100 \text { nautical } \\
\text { mile }\end{array}$ & $\begin{array}{c}\text { Number } \\
(\mathrm{n})\end{array}$ & $\begin{array}{c}\mathrm{n} / 100 \text { nautical } \\
\text { mile }\end{array}$ & Source \\
\hline 1989,1990 and 1992 & 161 & 2.682 & 265 & 4.414 & {$[14]$} \\
$1998-1999$ & 90 & 4.314 & 42 & 2.013 & {$[14]$} \\
2003 & 121 & 3.65 & 112 & 3.29 & From [19] \\
2009 & 97 & 5.834 & 31 & 1.865 & From [16] \\
2010 & 93 & 7.544 & 42 & 3.407 & From [17] \\
\hline
\end{tabular}

whales, but in summary reports shows tabular information on the number of finwhales on transects [13]-[18]. Since the surveys are conducted by the same method, and almost on the same routes, it is possible to compare the number of finwhales in Okhotsk Sea in time. From the data in Table 3 can be seen that in 1989, 1990 and 1992 abundance finwhales in Okhotsk Sea was 2.7 individuals per 100 nautical miles [15], in 2009 almost the same transects already 5.8 finwhales [16], and 7.0 individuals per 100 nautical miles in 2010 [17]. During our work in the summer of 2014 in the central part of Okhotsk Sea and off eastern Sakhalin were registered 8 to 10 individuals per 100 miles route (Table 1). If these figures are correct, abundance of finwhales in Okhotsk Sea during the last two decades has increased $2-3$ times.

In the available literature we could not find estimation of the number of finwhales in Okhotsk Sea. Because we received scattered and incidental information it is impossible to calculate the number of finwhales in the Okhotsk Sea in summer on our data. However, some comparisons can still be made. Previously, as a result of the Japan-Russian cruises, the number of minke whales in Okhotsk Sea was calculated [20]. According to these data, in the early 1990s, the estimated number of minke whales in the Sea of Okhotsk was 19,209 individuals 
(95\% confidence interval 10,000 - 36,000). In 1989-1990 and 1992 were recorded 265 minke whales and 161 finwhale, or 4.414 individuals of minke and 2.682 finwhales an average per 100 nautical miles accounting. That is, number of minke whales at that time is almost 2 times higher than number of finwhales [14]. In 2009 was accounted for 35 minke whales and 57 finwhales [16], in 2010 were registered 31 minke whales and 67 finwhales [17]. Thus, during last surveys on the same routes as in the 1990s, the number of finwhales exceeds the number of minke whales in 1.5 - 2 times. Minke poorly visible on the surface of the water because small size and weak blow. So, minke whales to miss much easier than finwhales during surveys. In the available literature we could not find estimated number of finwhales and current number of minke whales in Okhotsk Sea. Considering the important exceeding of the number finwhales over number of minke whales in the last surveys, suggests that number of finwhales in Okhotsk Sea, at least not lower number of minke whales.

Our information indicates that finwhales in Okhotsk Sea numerous enough in the April. April is transitional month from winter to spring, so there is a question about possibility winter habitation of finwhales in Okhotsk Sea. It is very little known about of the winter habitat areas of finwhales. A small number of finwhales hunted in the winter months from the coastal whaling stations of Japan, both on Pacific and Japan Sea side [3]. From 1916 until the mid 1930s Japanese and Korean whalers whaling 100 to 200 finwhales annually in the southern part of Japan and Yellow Seas near east and west coasts of Korea. Moreover, Sleptsov (1948 cited by [1]) wrote that in January - February, off western coast of Kamchatka can meet of wintering single finwhales.

Currently, International Whaling Commission considered of finwhales of the North Pacific as unitary unit (stock) of management, with the exception of animals living in the East China Sea [21]. Nevertheless, based on serological analysis and tagging [22] allocates western and eastern groups in the northern part of the Pacific. These groups are mixed in the area of the Aleutian Islands in summer. The author informs that the form of baleen plates of finwhales from the Okhotsk Sea is similar to form of baleen plates of finwhales harvested near north-east of Japan and the same form as the baleen plates of finwhales from the area of the Aleutian Islands. And their form differs against the baleen plate of finwhales from East China Sea.

As a most high-speed a species of whales, finwhale is able in a short period to cover long distances. It is very likely that in Okhotsk Sea we observed feed aggregation of finwhales. Recent decades there are a noticeable increase of the number of finwhale off shore to east of the Kuril Islands, Kamchatka Peninsula and to south of the Commander Islands [23]. In addition finwhales increased in the central Bering Sea [24]. Possible from these regions, as well as from Japan Sea, finwhales come up to Okhotsk Sea for summer feeding.

\section{Conclusions}

In last decades, we can see 2 - 3 multiple growth of abundance of finwhales in 
the Okhotsk Sea. Such a significant number of finwhales in these waters did not register earlier, neither in initial period of whaling or in the period of its development. At present the number of finwhales in Okhotsk Sea is comparable with the number of minke whales.

Certainly there is a need of modern estimation of the number of finwhales in Okhotsk Sea. This can be done through processing and summarizing of last materials of Japanese-Russian marine surveys in Okhotsk Sea.

\section{Acknowledgements}

We thank Dr. Vacheslav Lobanov and Aleksandr Sergeev from POI for help in organizing the scientific voyage in the Sea of Okhotsk.

\section{References}

[1] Tomilin, A.G. (1957) Zveri SSSR i prilezhashchikh stran. Kitoobraznye [Animals of the USSR and Adjacent Countries. Cetaceans]. Izdatelstvo Akademii Nauk SSSR [Soviet Academy of Sciences Publishers], Moscow, 756.

[2] Sleptsov, M.M. (1961) O kolebanii chislennosti kitov v Chukotskom more v raznye gody [Fluctuation in Numbers of Whales in the Chukchi Sea in Different Years]. Trudy Instituta morfologii zhivotnykh im. A.N. Severtsova [Transactions of the Severtsov Institute of Animal Morphology], Moscow, 54-64.

[3] Mizroch, S.A., Rice, D.W., Zwiefelhofer, D., Waite, J. and Perryman, W.L. (2009) Distribution and Movements of Finwhales in the North Pacific Ocean. Mammal Review, 39, 193-227. https://doi.org/10.1111/j.1365-2907.2009.00147.x

[4] Sleptsov, M.M. (1955) Promyslovyye kitoobraznyye severo zapadnoy chasti Tikhogo okeana, Okhotskogo i Beringova morey [Commercial Cetaceans Northwestern Pacific Okhotsk and the Bering Sea], Geograficheskoye rasprostraneniye ryb i drugikh promyslovykh zhivotnykh Okhotskogo i Beringova morey [The Geographical Distribution of Fish and Other Commercial Animals the Okhotsk and Bering Seas]. In: Rass, T.S., Kaganovski, A.G. and Kliumov, C.K., Eds., Trudy instituta okeanologii [Proceedings of the Institute of Oceanology], vol. 19, Russian Academy of Sciences, Moskow, 70-114.

[5] Sleptsov, M.M. (1955) Biologiya i promysel kitov Dalnevostochnykh morei [Biology and Hunting of Whales in the Far Eastern Seas]. Pishchepromizdat, Moscow, 62.

[6] Berzin, A.A. and Vladimirov, V.L. (1989) Sovremennoye raspredeleniye i chislennost' kitoobraznykh v Okhotskom more [Modern Distribution and Abundance of Cetaceans in the Okhotsk Sea]. Russian Journal of Marine Biology, 2, 15-23.

[7] Schuntov, V.P. (1993) Sovremennoye rasprostraneniye kitov i del'finov v Dal'nevostochnykh morya i sopredel'nykh vodakh Tikhogo okeana [The Current Distribution of Whales and Dolphins in the Far Eastern Sea and Adjacent Waters of the Pacific Ocean]. Zoological Journal, 72, 131-141.

[8] Vladimirov, V.L. (1994) Sovremennoye raspredeleniye i chislennost' kitov v dalnevostochnykh moriakh [Modern Distribution and Numbers of Whales in Seas of the Far East]. Russian Journal of Marine Biology, 20, 3-13.

[9] Schuntov, V.P. (1999) Nekotorie osobennosti sovremennogo raspredeleniya kitov i del'finov v Okhotskom More [Some Features of the Modern Distribution of Whales and Dolphins in Okhotsk Sea]. Okeanologiya, 39, 253-257.

[10] Sobolevsky, E.I. (1983) Morskiye mlekopitayuchie Okhotskogo morya, ih raspredeleniye, chislennost' i rol' kak potrebiteley drugikh zhivotnykh [Marine Mammals of 
Okhotsk Sea, Their Distribution, Abundance and Role as Consumers of Other Mammals]. Russian Journal of Marine Biology, 5, 15-20.

[11] Rovnin, A.A. (1967) Razvedka i mecheniye kitov v zapadnoy chasti Tikhogo okeana, Filippinskom, Okhotskom, Beringovom i Chukotskom moryakh. Otchet po nauchno-poiskovomu reysu SRT "Vityaz" v 1967 godu [Investigation and Tagging of Whales Western Pacific Ocean, the Philippines, the Okhotsk, Bering and Chukchi Seas. Scientific Report on Exploratory Voyage of Ship "Vityas" in 1967]. Archives TINRO No. 10948, Vladivostok, 1-31.

[12] Schuntov, V.P. (1994) New Data on the Distribution of Whales and Dolphins in the Northwestern Pacific. Russian Journal of Marine Biology, 20, 436-442.

[13] Miyashita, T. and Doroshenko, N.V. (2000) Cruise Report of the Japan-Russia Joint Sighting Survey in the Sea of Okhotsk in 1999. Paper SC/52/RMP4 Presented to the IWC Scientific Committee, 1-5.

[14] Vladimirov, A.V., Miyashita, T. and Okamura, H. (2001) New Data on the Distribution of Cetaceans in Okhotsk Sea (Based on the Results of 1998-1999 Surveys) Results of the Far East Marine Mammal Researches in 1991-2000. In: Vladimirov, A.V., Eds., Materials of the 16th Working Group Meeting under Project 02.05-61 "Marine Mammals" within the Framework of the US-Russia Agreement on Cooperation in the Field of Environmental Protection, VNIRO Publishing, Moscow, 205-210.

[15] Vladimirov, A.V., Miyashita, T., Khayashi, N., Saito, T., Tokuda, D. and Shvetsov, E.P. (2004) Distribution of Cetaceans in the Sea of Okhotsk in July-September, 2003. Marine Mammals of Holarctic, Proceedings of 3rd International Conference, Koktebel, 11-17 October 2003, 136-140.

[16] Yoshida, H., Kanaji, Y., Miyashita, T., Uoya, T. and Furukawa, H. (2010) Cruise Report of the Common Minke Whale Biopsy Sampling Survey in the Okhotsk Sea, Summer 2009. Paper SC/62/NPM22 Presented to the IWC Scientific Committee, $1-10$.

[17] Yoshida, H., Kishiro, T., Kanda, N. and Miyashita, T. (2011) Cruise Report of the Sighting and Biopsy Sampling Survey in the Okhotsk Sea, Summer 2010, Including Individual Stock Identification of Common Minke Whales. Paper SC/63/RMP9 presented to the IWC Scientific Committee, 1-10.

[18] Istomin, I.G., Tatarnikov, V.A., Zharikov, K.A., Miyashita, T. and Akishin, V.V. (2013) Observation of Cetaceans in the Sea of Okhotsk in 2009-2010. The Researches of the Aquatic Biological Resources of Kamchatka and the North-West Part of the Pacific Ocean 28, 116-128.

[19] Vladimirov V.A. (2002) To Assessment of the Minke Whale Number in the Sea of Okhotsk//Marine Mammals of Holarctic. Proceeding of Reports the 2nd International Conference, Baikal, 10-15 September 2002, 66-68.

[20] Buckland, S.T., Cattanach, K.L. and Miyashita, T. (1992) Minke Whale Abundance in the Northwestern Pacific and the Okhotsk Sea, Estimated from 1989 and 1990 Sighting Surveys. Report of the International Whaling Commission, 42, 387-392.

[21] Donovan, G.P. (1991) A Review of IWC Stock Boundaries. Report of the International Whaling Commission, 13, 39-63.

[22] Fujino, K. (1960) Immunogenetic and Marking Approaches to Identifying SubPopulations of the North Pacific Whales. Science Report Whales Research Institute, 15, 84-142.

[23] Kornev, S., Miyashita, T., Saito, T., Hiruda, H. and Gusakov, P. (2006) Results of Survey of Cetaceans in the Northvestern Pacific in 2005. In: Belkpvich, V.M., Eds., Marine Mammals of Holarctic, Marine Mammal Counsil, Leningrad, 256-261. 
[24] Moore, S.E., Waite, J.M., Friday, N.A. and Honkalento, T. (2002) Cetacean Distribution and Relative Abundance on the Central-Eastern and the Southeastern Bering Sea Shelf with Reference to Oceanographic Domains. Progress in Oceanography, 55, 249-261. https://doi.org/10.1016/S0079-6611(02)00082-4

Submit or recommend next manuscript to OALib Journal and we will provide best service for you:

- Publication frequency: Monthly

- 9 subject areas of science, technology and medicine

- Fair and rigorous peer-review system

- Fast publication process

- Article promotion in various social networking sites (LinkedIn, Facebook, Twitter, etc.)

- Maximum dissemination of your research work

Submit Your Paper Online: Click Here to Submit

Or Contact service@oalib.com 